\title{
Édouard Glissant, 10 Mai. Mémoires de la traite négrière, de l'esclavage et de leurs abolitions
}

\section{Luigia Pattano}

\section{(2) OpenEdition}

10 Journals

\section{Édition électronique}

URL : http://journals.openedition.org/studifrancesi/6468

DOI : 10.4000/studifrancesi.6468

ISSN : 2421-5856

Éditeur

Rosenberg \& Sellier

\section{Édition imprimée}

Date de publication : 1 novembre 2010

Pagination : 602-603

ISSN : 0039-2944

\section{Référence électronique}

Luigia Pattano, «Édouard Glissant, 10 Mai. Mémoires de la traite négrière, de l'esclavage et de leurs abolitions », Studi Francesi [En ligne], 162 (LIV | III) | 2010, mis en ligne le 30 novembre 2015, consulté le 08 janvier 2021. URL : http://journals.openedition.org/studifrancesi/6468 ; DOI : https://doi.org/ 10.4000/studifrancesi.6468

Ce document a été généré automatiquement le 8 janvier 2021.

\section{(c)}

Studi Francesi è distribuita con Licenza Creative Commons Attribuzione - Non commerciale - Non opere derivate 4.0 Internazionale. 


\title{
Édouard Glissant, 10 Mai. Mémoires de la traite négrière, de l'esclavage et de leurs abolitions
}

\author{
Luigia Pattano
}

\section{RÉFÉRENCE}

ÉDOUARD GLISSANT, 10 Mai. Mémoires de la traite négrière, de l'esclavage et de leurs abolitions, Paris, Galaade, 2010, pp. 52.

1 À l'occasion des célébrations officielles du 10 mai, date établie par l'État français pour remémorer, une fois par an, les abolitions de la traite négrière et de l'esclavage remontant à 1848 pour les anciennes colonies françaises de la Caraïbe (à l'exception de celle qui arracha la première son indépendance en 1804 et qui se renomma Haïti), Édouard Glissant et l'Institut du Tout-Monde publient, chez Galaade, une anthologie de textes sur la traite négrière, l'esclavage et leurs abolitions. Présenté le soir du 10 mai 2010 à la Maison des Métallos (Paris, 11 arrondissement), où plusieurs acteurs se succédèrent sur scène dans la lecture de ces quelques «textes qui ont fait et défait les esclavages», le dernier ouvrage signé par le poète martiniquais témoigne d'un double but, politique et heuristique à la fois, si l'on s'en tient à «Mémoires des esclavages», son réjouissant avant-propos.

2 Rappeler ce que fut ce crime contre l'humanité à travers les voix de ceux qui luttèrent pour son abolition, et réitérer ainsi la dénonciation de toute forme d'esclavage, reste en effet, pour l'écrivain, une nécessité qui concerne tous aujourd'hui car «ce phénomène global de transformation du monde qu'a été l'esclavage» et les réalités dans lesquelles il se développa, à savoir les colonisations, sont à l'origine de, et donc expliquent, la totalité-monde actuelle (c'est ainsi que Glissant nomme la situation mondiale actuelle dans ses relations, ou mieux dans son caractère inévitablement relationnel). «Les mémoires des esclavages en reviennent à ceci: concilier les mémoires contradictoires 
des formes d'organisation esclavagiste et, sinon extirper tous les contours d'obscurité de cet énorme régime, du moins concevoir sa fonction dans la préorganisation du monde moderne. Rendre aussi les mémoires fraternelles». La fonction cognitive première de ce travail se double par conséquent d'une nécessité poétique, celle d'«ouvrir les chemins de la Relation mondiale», qui serait justement dictée «de la poétique du partage, de la différence consentie, de la solidarité des devenirs naturels et culturels, qui décide d'une communauté de politiques appropriées à mettre en œuvre (de manière singulière mais concordante), dans les diverses situations du monde».

«Personnels ou publics», «d'analyse ou d'action», «de l'iniquité ou de la libération, proclamations ou ordonnances, confidences ou lamentations, poèmes ou appels», les trente-six extraits rassemblés dans cet ouvrage représentent alors les jalons d'un chemin que Glissant et ses collaborateurs nous proposent de suivre. Ceux qui choisiront de le faire y trouveront quelques précieux témoignages de la traite et de la vie des esclaves dans l'habitation réalisés par les célèbres prêtres catholiques qui vécurent aux Antilles, des références législatives fondamentales (une partie du Code noir, les décrets d'abolitions et celui de rétablissement de l'esclavage), quelques discours d'abolitionnistes célèbres, français et américains, et quelques appels pour l'abolition émanant du peuple. Le lecteur trouvera à la fin de l'ouvrage une sélection littéraire: un passage du premier roman d'Hannah Crafts, Autobiographie d'une esclave, de 1850; un extrait du poème dédié «Au très honorable Compte de Darmouth, principal secrétaire d'Etat de Sa Majesté pour l'Amérique» de Phillis Wheatley; La traversée de Robert Hayden; deux strophes sur la traite tirées des Indes d'Édouard Glissant; un extrait du poème dramatique Et les chiens se taisaient d'Aimé Césaire (d'après l'édition de 1956 de Présence africaine); et If we must die de Claude McKay. 